
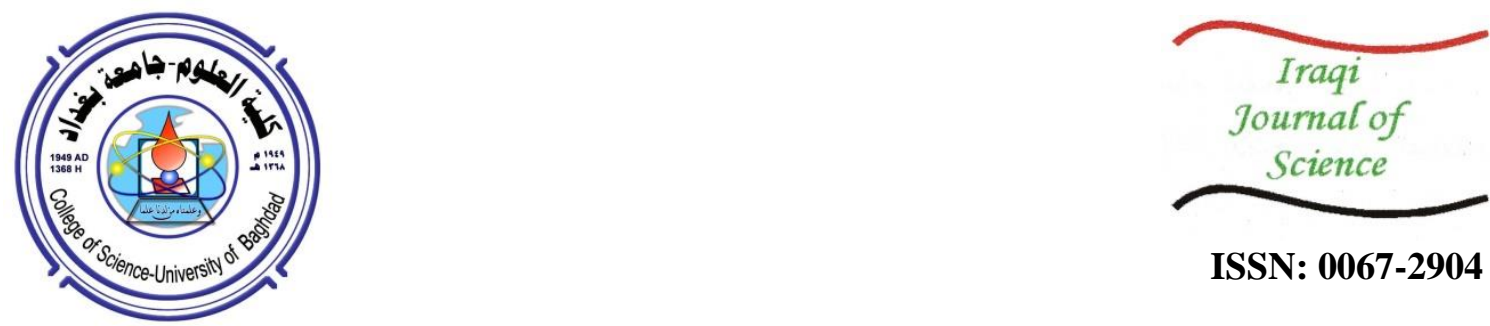

ISSN: 0067-2904

\title{
Representative Sector Modeling and Waterflooding Performance in Rumaila Oilfield
}

\author{
Mustafa Kamil Shamkhi*, Mohammed Salih Aljawad \\ Petroleum Department, College of engineering, University of Baghdad, Baghdad, Iraq
}

Received: 25/12/2019

Accepted: 7/4/2020

\begin{abstract}
Rumaila supergiant oilfield, located in Southern Iraq has a huge footprint and is considered as the second largest oilfield in the world. It contains many productive reservoirs, some known but without produced zones, and significant exploration potential. A fault divides the field into two domes to the north and south. Mishrif reservoir is the main producing reservoir in the North Rumaila oilfield. It has been producing for more than 40 years and is under depletion. However, it was subjected to water injection processes in 2015, which assisted in recovery and pressure support. Thus, requirements of managing flooding strategies and water-cut limitations are necessary in the next stages of the field life.

In this paper, sector modeling was applied to a specific portion of the field, rather than full-field modeling, to accelerate history matching strategy and correlate static to dynamic models' efficiently, with a minimum level of tolerance. The sector was modeled by surrounding with additional grid blocks and two pseudo wells to achieve a good matching with actual available data.

PVT data were used for fluid modeling of a well contained in the sector, and two rock functions were inserted to the model to achieve acceptable history matching. Twelve wells were considered in this research, two of them were injectors and the remaining are producers. For future performance, some of these wells were subjected to new completion and workover processes for field development and pressure maintenance. The importance of the development plan is to represent a way for field development without new wells to be drilled. This was conducted by adding perforations to some wells, plugging the high water-cut production zones, changing production and injection rates, and converting the producers to injectors.
\end{abstract}

Keywords: Sector modeling; Future performance; Mishrif Reservoir/Rumaila Oilfield.

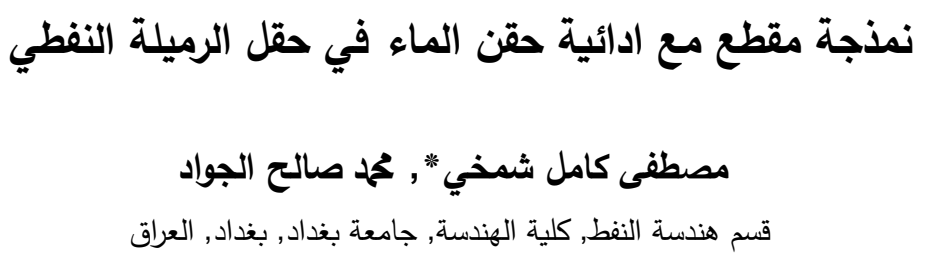

الخلاصة

حقل الرميلة النفطي العملاق بمساحات ضخمة يقع جنوبي العراق, ثاني اكبر حقل في العالم, عدة مكامن

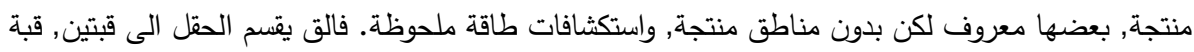

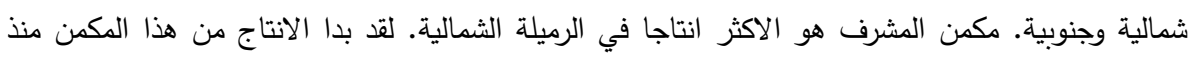

اكثر من 40 سنة تحت تاثير الاستنزاف. مع ذلك, تعرض الدكمن الى عمليات حقن الماء في عام 2015,

*Email: mustafakamel268@yahoo.com 


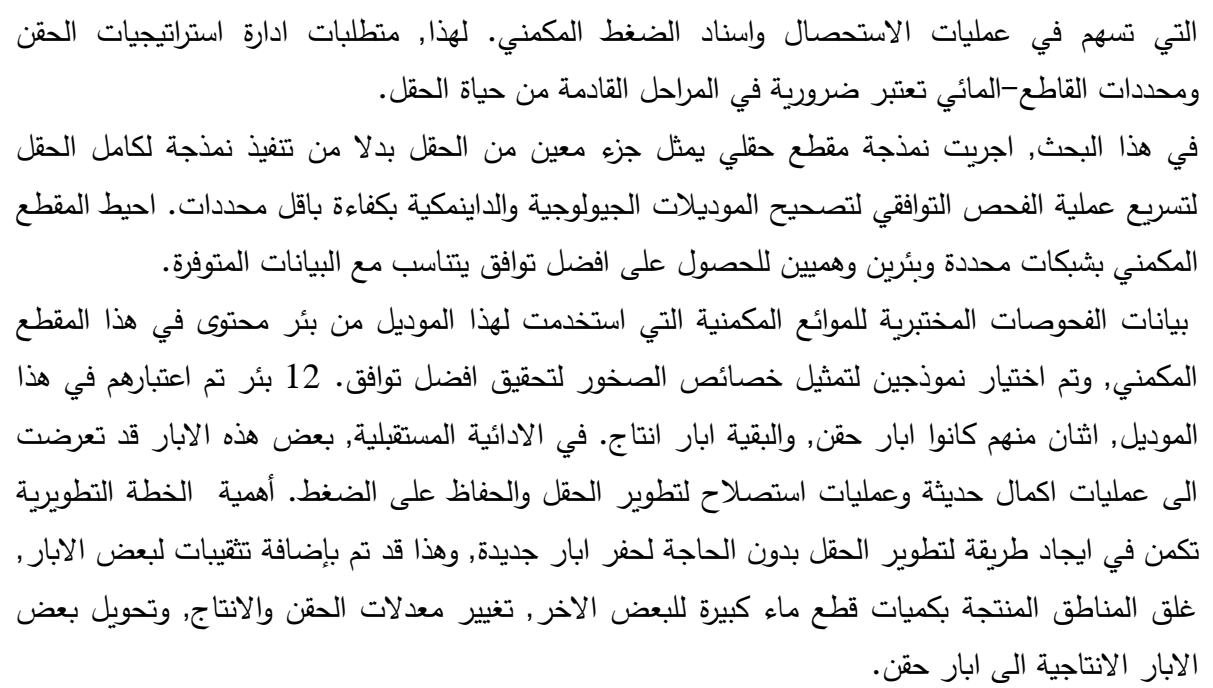

\section{1- Introduction}

The multi-layered productive zones with large footprint in North-Rumaila oilfield, located in Basra/Southern Iraq, are composed mainly of carbonate rocks and separated from the south dome by a fault. The field structure is dipping gently, composed of two domes (North and South Rumaila) separated from each other by saddle. The extent of the structure is approximately $120 \mathrm{Km}$ long and about $15 \mathrm{Km}$ wide. The main oil-bearing reservoirs are Mishrif (this case study) and Mainpay. The composition of Mishrif is of shallow water carbonate, which is deposited throughout the Upper Cretaceous in the Cenomanian age. Generally, in many oilfields in the southern part of Iraq and neighboring countries, Mishrif reservoirs are prolific [1].

Essentially, although the reservoirs produce under depletion or waterflooding recovery, they require full realization and monitoring to be managed effectively. A reservoir management is the group of serial activities related to the analysis of reservoir models (geological and numerical models) and field production data. These activities are utilized to develop and exploit a reservoir to realize a maximum hydrocarbon recovery with low economic cost. The beneficial outcome of reservoir simulation is to ensure the validity of the current strategy of reservoirs and promote a convenient future schema for any field $[2,3]$.

Developing a full simulation study of large oil fields requires upscaling of the geological models that might minimize the level of detalization and inevitably. However, additional errors can be resulted in the simulation process due to this upscaling [4]. Moreover, the simulation runs for large fields would take long time. Sector modeling is more convenient to represent a comprehensive field and can accelerate reservoir simulations and characterizations by focusing on the sector only. This helps to construct both geological and dynamic models quickly and easily $[5,6]$.

\section{2- Reservoir Description}

The Mishrif formation is composed of shallow water carbonates, deposited during the Upper Cretaceous/ Cenomanian period. The broad shallow water carbonate platform extends from Southern Turkey, through Iraq and the Arabian Peninsula, to Somalia. The Mishrif formations in Iraq overlie deeper-water oligostenid carbonates of the Rumaila formations in a belt between the Iraq-Iran border to the Northwest and the Basra area in Southeast Iraq.

The deposition of Mishrif formation was part of a second order sequence spanning from the Lower Cenomanian (top of the Mauddud) to the Lower Turonian (Top of the Mishrif). Historically, the reservoir zonation over the Rumaila Field was divided into $\mathrm{mA}$ (above) and $\mathrm{mB}$ (below) with cap rocks (CR) above these reservoir layers, which are tight zones. The new interpretations of Mishrif reservoir is recognized by five 3rd-order sequences in Rumaila field. The $\mathrm{mB}$ is subdivided into three 3rd-order sequences (Mhf1, Mhf2 and Mhf3 from base to top) while the mA is composed of two 3rdorder sequences (Mhf4 and Mhf5).

\section{2-1 Rock properties}

Essentially, understanding the main rock properties that control flow in porous medium is a precondition to understanding water flooding performance and how it should be designed and controlled. Some of these rock properties are related to the properties of rock material alone; for 
example, permeability, porosity, surface area and pore throat distribution. While others are concerned with properties of the interaction of the contained rock and fluid including wettability, capillary pressure and relative permeability $[8,9]$.

In Mishrif reservoir of Rumaila field, the independent porosity is obtained from Density-Neutron logs, after correction of shale content and calibrated with core porosity is displayed in CPI. However, the permeability is calculated based on the hydraulic flow unit (HFU) concepts using FZI (Flow Zone Indicator) and RQI (Reservoir Quality Index) parameters in the following equations:

$$
\begin{aligned}
& \mathrm{RQI}=0.0314 \sqrt{\frac{K}{\emptyset \boldsymbol{e}}} \\
& \varnothing \mathrm{z}=\frac{\emptyset \boldsymbol{e}}{1-\emptyset \boldsymbol{e}} \\
& \mathrm{FZI}=\frac{1}{\sqrt{\mathrm{F}_{\mathrm{s}}} \tau \mathrm{S}_{g v}}=\frac{R Q I}{\emptyset \mathrm{z}} \\
& \log (\mathrm{RQI})=\log (\emptyset \mathrm{z})+\log (\mathrm{FZI})
\end{aligned}
$$

Finally, the following equation is applied for permeability prediction:

where:

$$
\mathrm{K}=1014 F Z I^{2} \frac{\emptyset e^{3}}{(1-\varnothing e)^{2}}
$$

$\mathrm{K}$ : permeability $\left(\mu \mathrm{m}^{2}\right)$,

$\emptyset e$ : effective porosity (fraction),

RQI: Reservoir Quality Index $(\mu \mathrm{m})$,

$\varnothing \mathrm{z}$ : the ratio of pore volume to the grain volume (fraction),

FZI: Flow Zone Indicator $(\mu \mathrm{m})$.

Based on equation (2-4), a plot of RQI versus $\emptyset_{z}$ on log-log paper yields a unit slope straight line for core samples with similar values of FZI. However, core samples with different FZI values will lay on different parallel a unit slope line. FZI is a unique and homogeneous property that is considered constant within a specific flow unit. Data that have similar values of FZI lie on the same straight line and may consider having similar pore throats attributes, represented by HFU. FZI value for each one of these flow units is specified by the interception of the straight line at $\varnothing_{\mathrm{z}}$ equal to one. Unfortunately, the concept of flow units with the same slope of the straight lines is not always the case, as Civan (2002) and Haro and Oil (2004) showed that reservoir rock systems tend to show various rather than similar slopes.

Figure-1 shows a log-log cross plot of (RQI) versus $\left(\emptyset_{z}\right)$ obtained from core data analysis. This plot shows a different HFU with different values of FZI. The permeability-porosity cross plot of these units is displayed in Figure-2. Depending on the well logs response and final well report (FWR), FZI values were distributed among the reservoir major units, where the unit with good properties has taken a higher FZI value and so on. Based on these subdivisions, the permeability value was obtained using equation (2-5) and FZI values were specified for each subunit. Figure-3 shows the plot of core and predicted permeability versus depth, which gives an acceptable agreement between core permeability and K-calculated from FZI approach. Based on CPIs for each well, which included all parameters that describe the formations such as log porosity, resistivity, water and hydraulic saturations, and final well report (FWR), the unit with good properties has taken higher FZI values and so on.

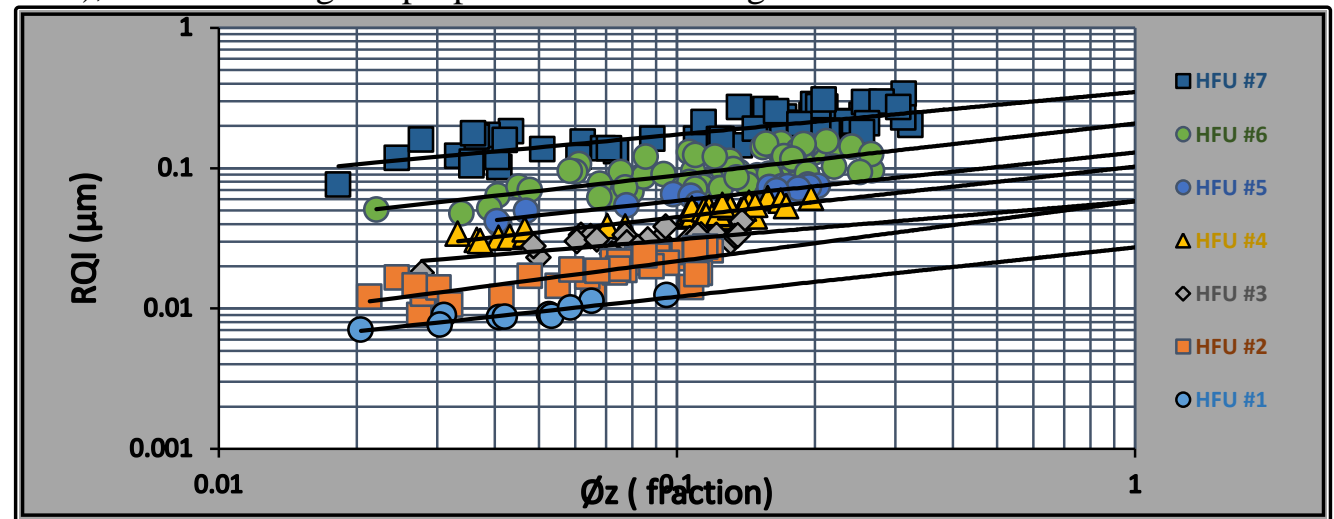

Figure 1-Log-log cross plot of RQI versus $\emptyset \mathrm{z}$, which shows seven separated hydraulic flow unit. 


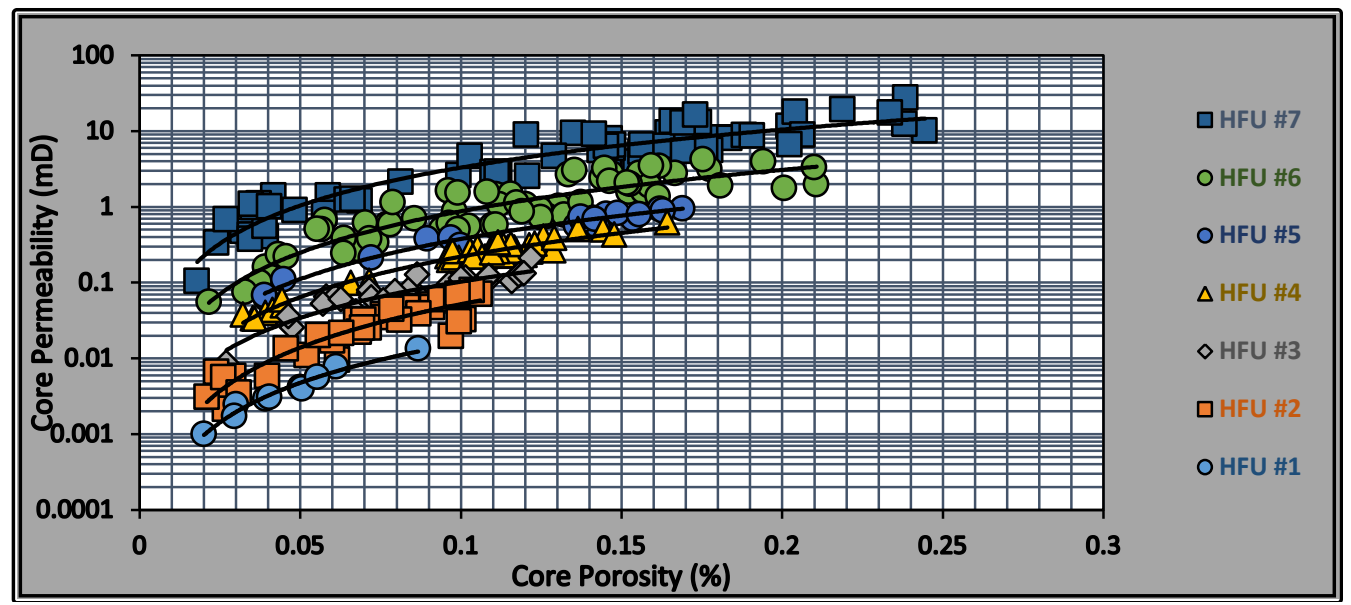

Figure 2- Semi log plot of core permeability versus core porosity for each hydraulic flow unit.

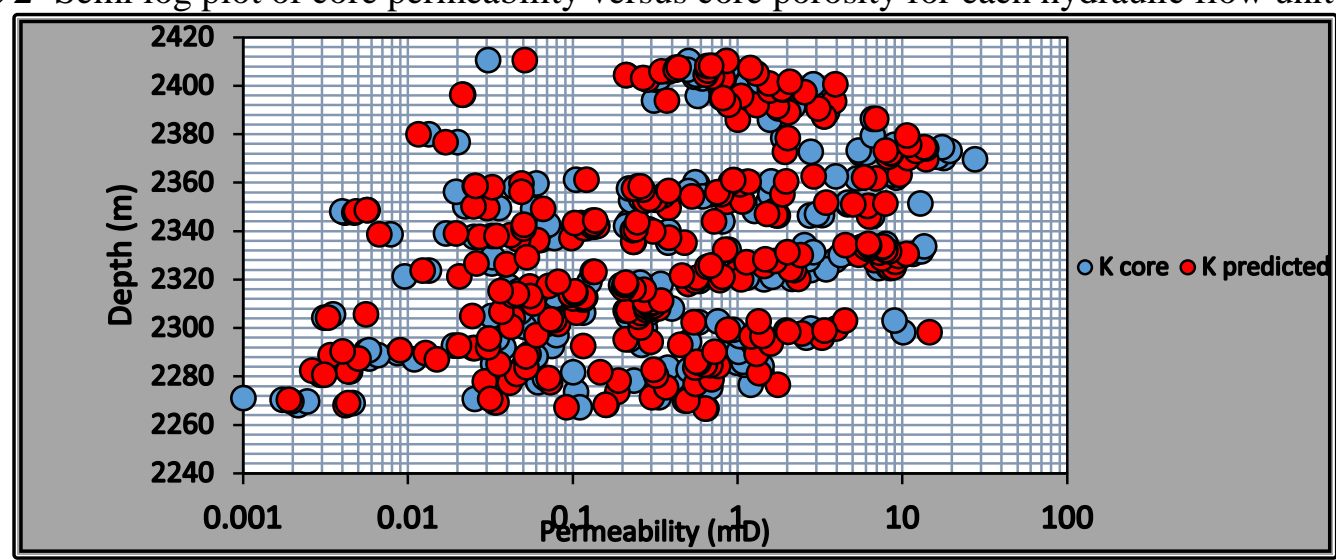

Figure 3-K values predicted by HUF method and from cores versus depth.

Capillary pressure and relative permeability curves, that describe the movement of any single fluid in presence of others, are selected from special core analyses displayed in Figures- 4 to 6 . In this model, two rock functions are inserted in PETREL to represent two different units, which are mA (Unit 2) and $\mathrm{mB}$ (Unit 1).

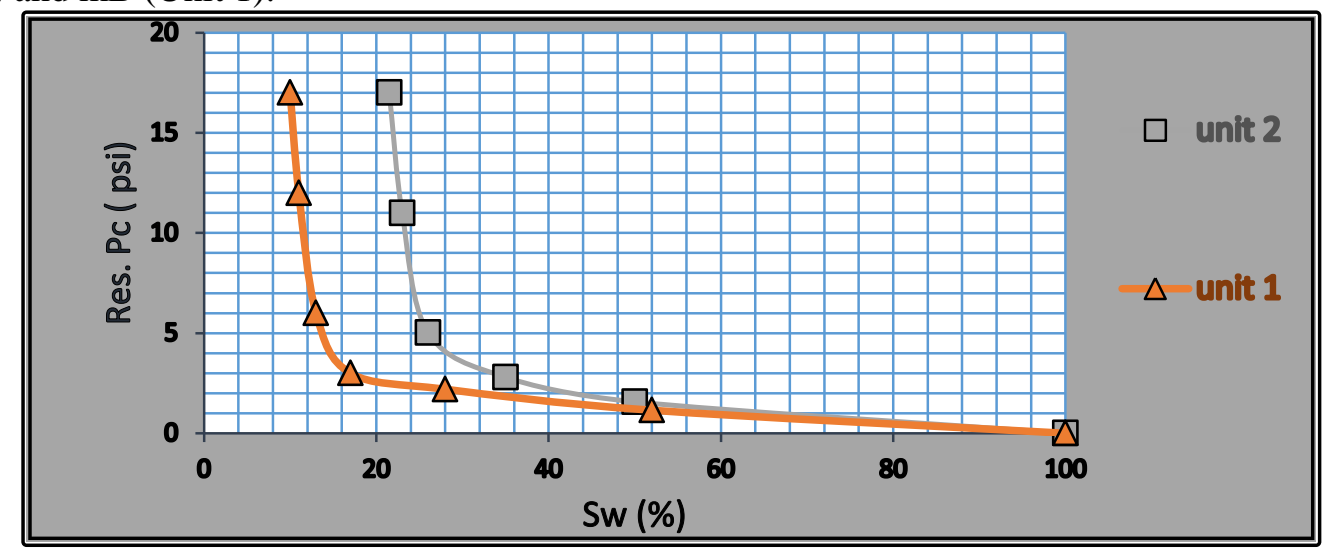

Figure 4-Pc curves for all units of the Mishrif reservoir. 


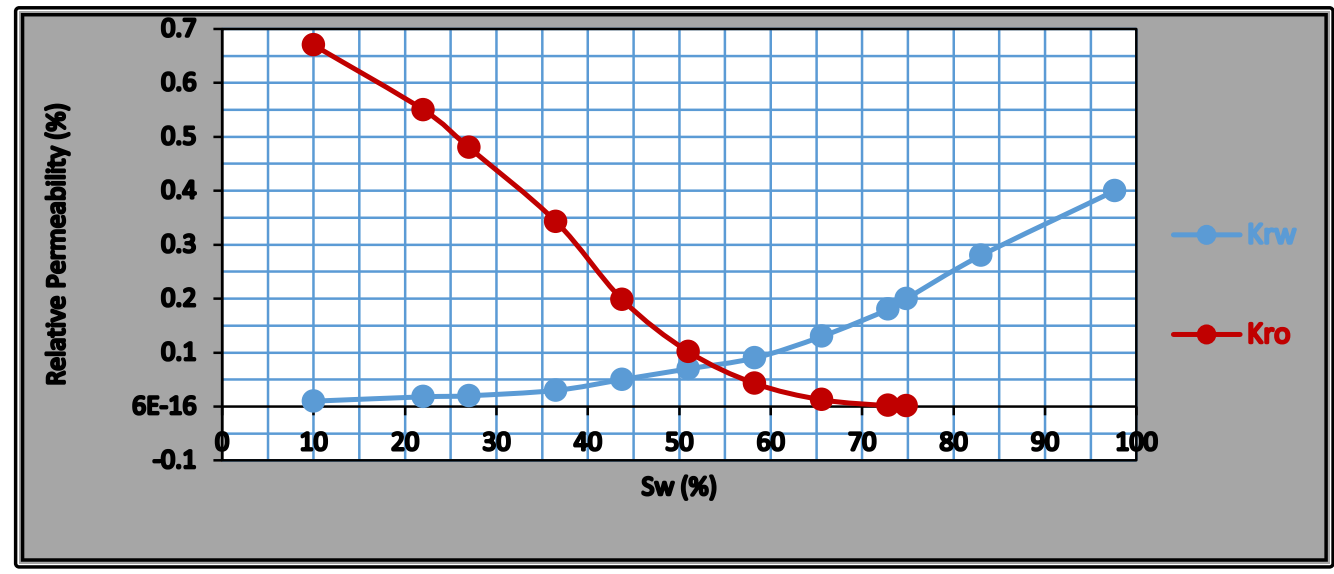

Figure 5-Relative permeability of water-wet system $(\mathrm{mB})$.

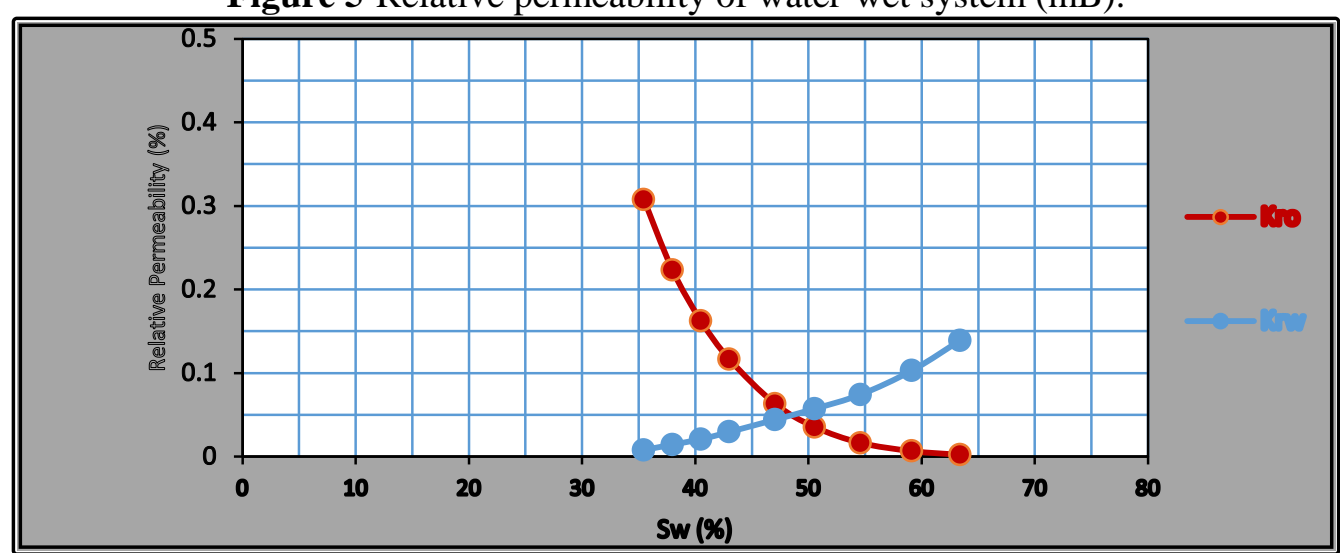

Figure 6-Relative permeability of oil-wet system (mA).

The calculations of water saturation depended on the open hole well log analysis in CPI and then distributed as a surface map in a static model (geological model).

\section{2-2 Fluid Properties}

The black oil reservoir of Mishrif formations/ North Rumaila oilfield was found to be with an undersaturated oil phase without gas cup, since all logs showed no evidence of gas and, hence, the reservoir fluid is initially liquid. The initial reservoir properties are shown in table_1, with initial reservoir pressure and temperature values, respectively, of about $3900 \mathrm{psi}$ and $170 \mathrm{~F}^{\circ}$. PVT analysis of three samples of different wells was relied upon for gathering hydrocarbon properties. These wells are R-024, R-059 that is involved in the sector modeling, and R-083.

Table 1-Hydrocarbon properties at initial conditions of Mishrif reservoir

\begin{tabular}{|c|c|c|c|}
\hline $\begin{array}{c}\text { Saturation Pressure } \\
\text { (psia) }\end{array}$ & $\begin{array}{c}\text { Gas Oil Ratio } \\
\text { (scf/stb) }\end{array}$ & $\begin{array}{c}\text { Stock Tank Gravity } \\
\text { (API) }\end{array}$ & $\begin{array}{c}\text { Viscosity at Initial } \\
\text { Reservoir Pressure } \\
\text { (cP) }\end{array}$ \\
\hline $1650-2400$ & 585 & 25.8 & 1.32 \\
\hline
\end{tabular}

PVT analysis of oil properties, including viscosity, formation volume factor, and in-solution and liberated gas to oil ratio of Mishrif reservoir were displayed as a function of pressure, as shown in Figures-7 through 9, respectively. Average oil density of Mishrif formation is about $0.9 \frac{\mathbf{g m}}{\mathbf{c m}^{3}}$ while that for the gas phase is about 0.765 (air=1.0).

The characteristics of reservoir water for Mishrif formation in North Rumaila field are listed in Table-2. 


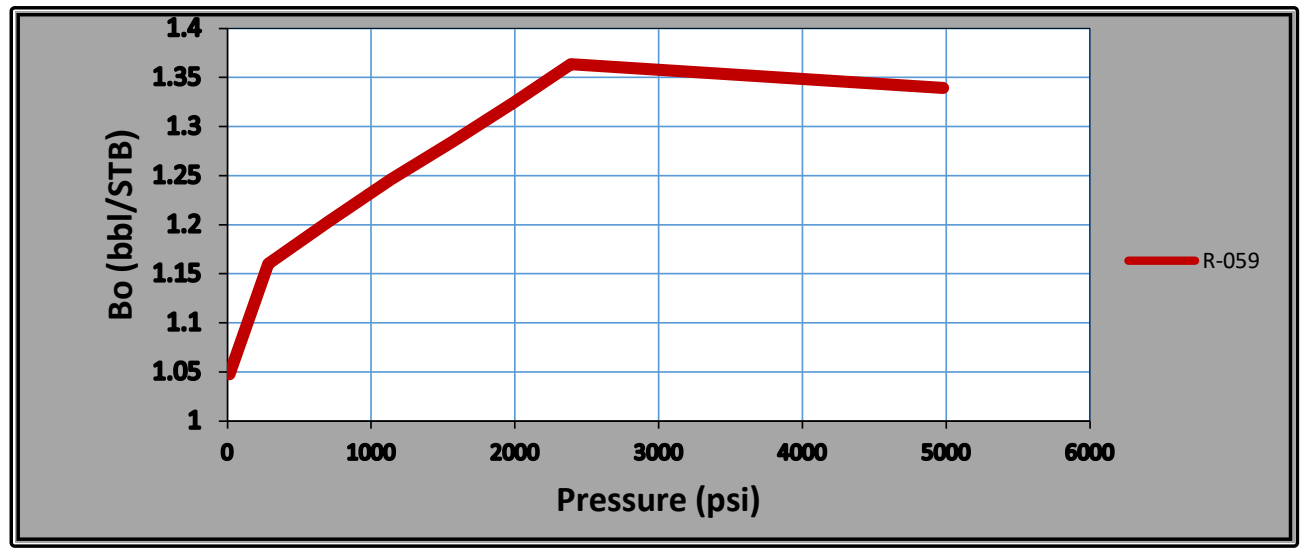

Figure 7- Oil formation volume factor versus pressure.

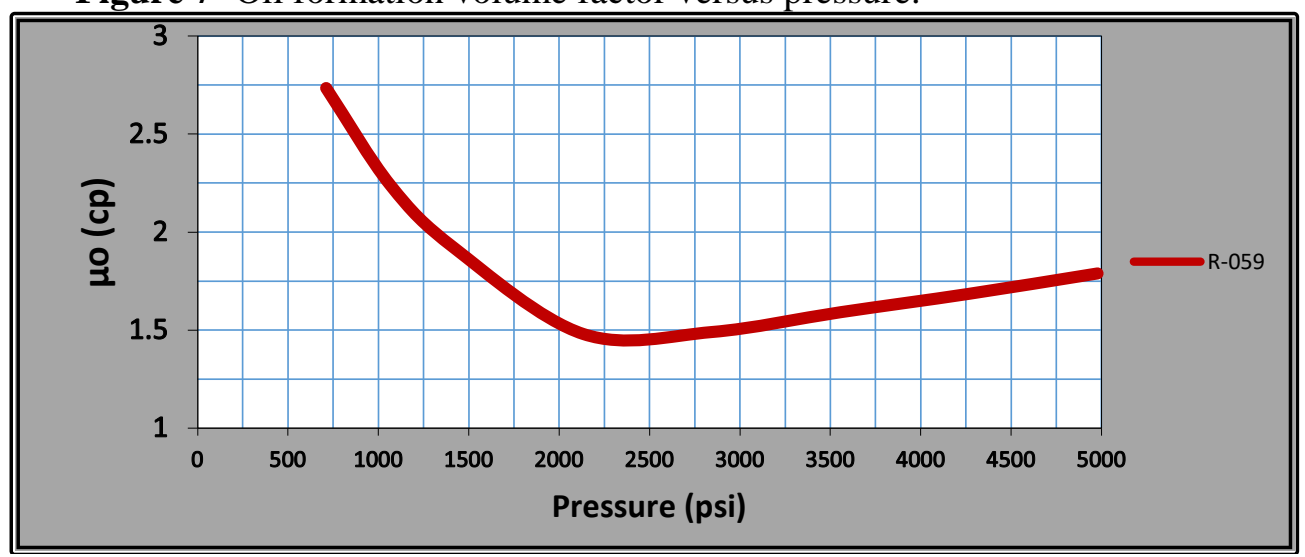

Figure 8-Oil viscosity versus pressure.

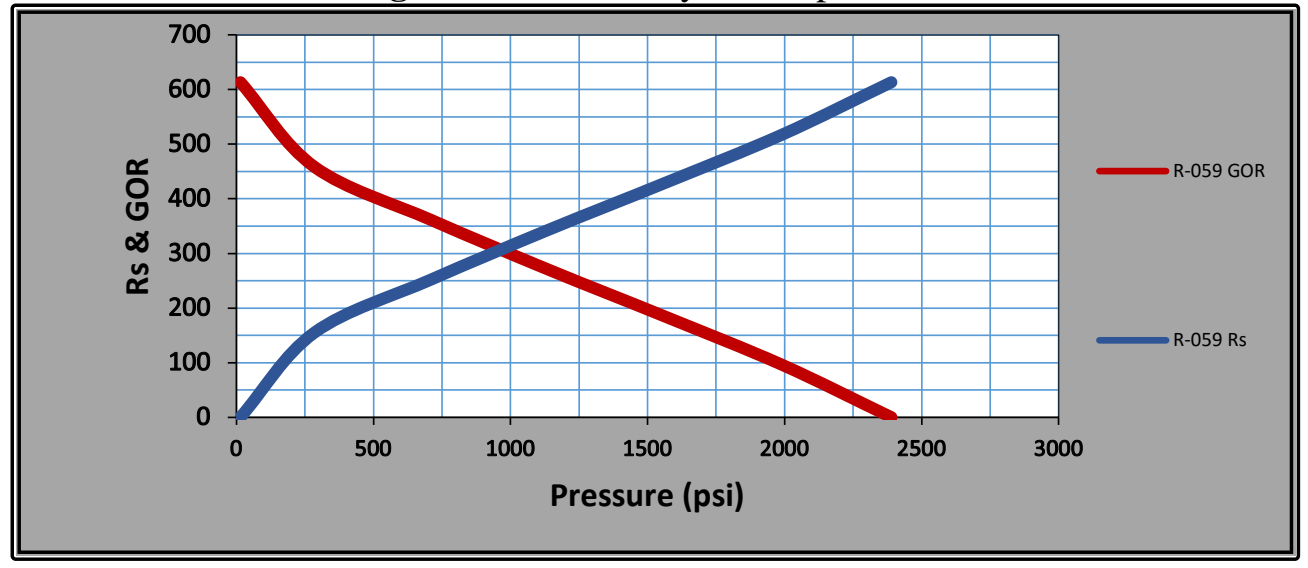

Figure 9-Liberated and in-solution gas to oil ratio versus pressure.

Table 2-Formation water properties of Mishrif reservoir

\begin{tabular}{|c|c|}
\hline $\begin{array}{c}\text { Density } \\
\text { (g/cc) }\end{array}$ & 1.09 \\
\hline Water comp. (psia-1) & $2.23 \times 10^{-6}$ \\
\hline Water FVF (rb/stb) & 1.023 \\
\hline $\begin{array}{c}\text { Viscosity } \\
(\mathbf{c P})\end{array}$ & 0.531 \\
\hline $\begin{array}{c}\text { Water salinity } \\
(\text { PPK) }\end{array}$ & 180 \\
\hline
\end{tabular}




\section{3- $\quad$ Reservoir Modeling}

Geological or static modeling of a reservoir is the technique of constructing a stratigraphic and structural reservoir model depending on the analysis and interpretation of core data, well log data, seismic data and fluid flowing data. The static model describes the reservoir quantitatively and is employed as input in the simulator programs, which finally assists in initially estimating reservoir hydrocarbon volume and future performance. This section focuses on building a 3D geological model of Mishrif formation in North Rumaila oilfield based on the available core and log data, followed by numerical modeling and finally history matching.

The surface map with well locations is shown in Figure-10. The first step of building the structural model was constructing 3D maps for each main zone in the reservoir depending on input data, which are represented by well head (well position in three-dimensional coordinates), well tops, and contour map.

After defining the 3D maps, a 3D geocellular grid was constructed from the horizon modeling and limited the area encompassed by the Rumaila concession that divides the sector into small boxes. However, each one of these boxes represents a grid cell with specific properties, such as permeability, porosity, saturation, rock type and fluid production parameters, including pressures and flow rates. Horizontal resolution was set to $200 \mathrm{~m}$ by $200 \mathrm{~m}$ in the X and Y directions and the grid rotation was left as 0 degree (i.e. aligned approximately north to south). Consequently, the model gridding represents three- main skeletons of the reservoir that are illustrated in Figure-11.

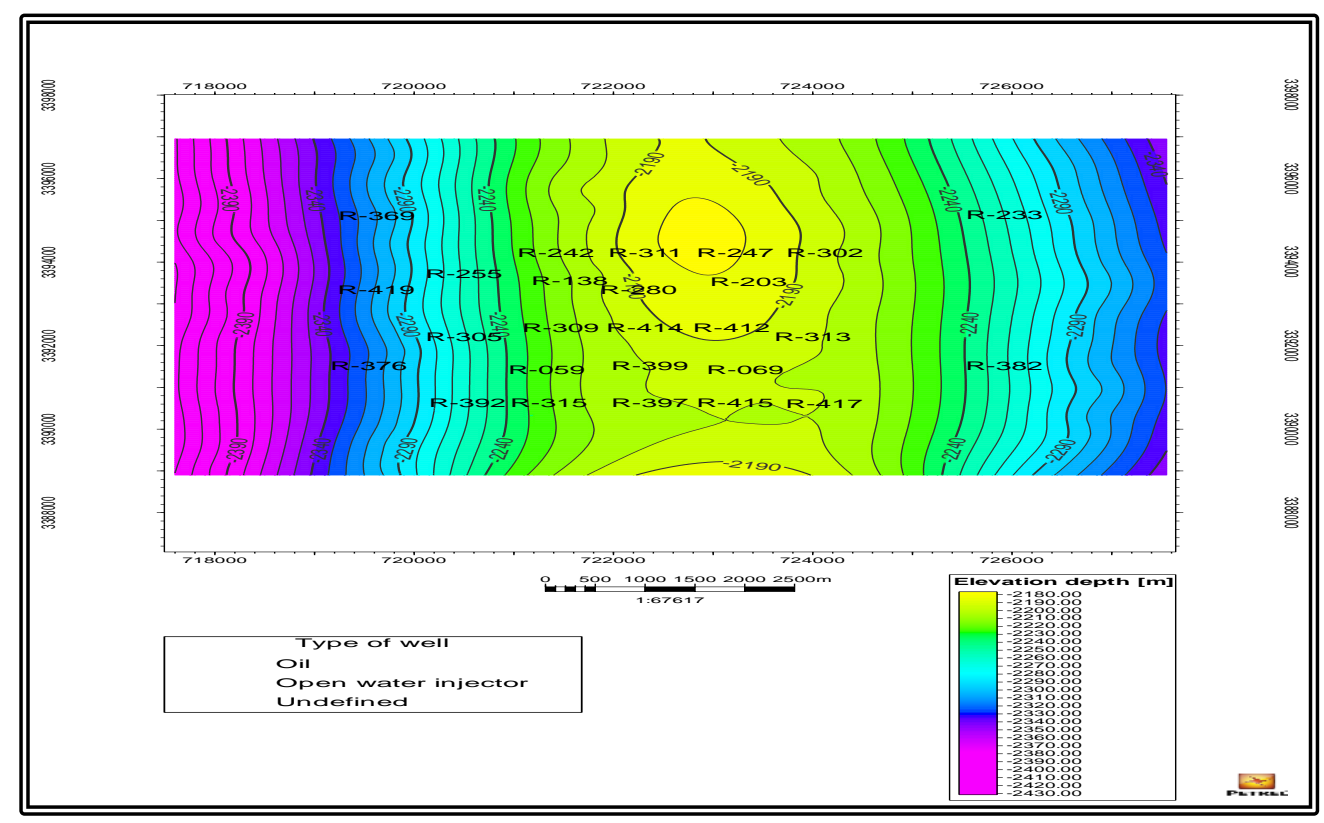

Figure 10-Wells location in the structural map of Mishrif formation. 


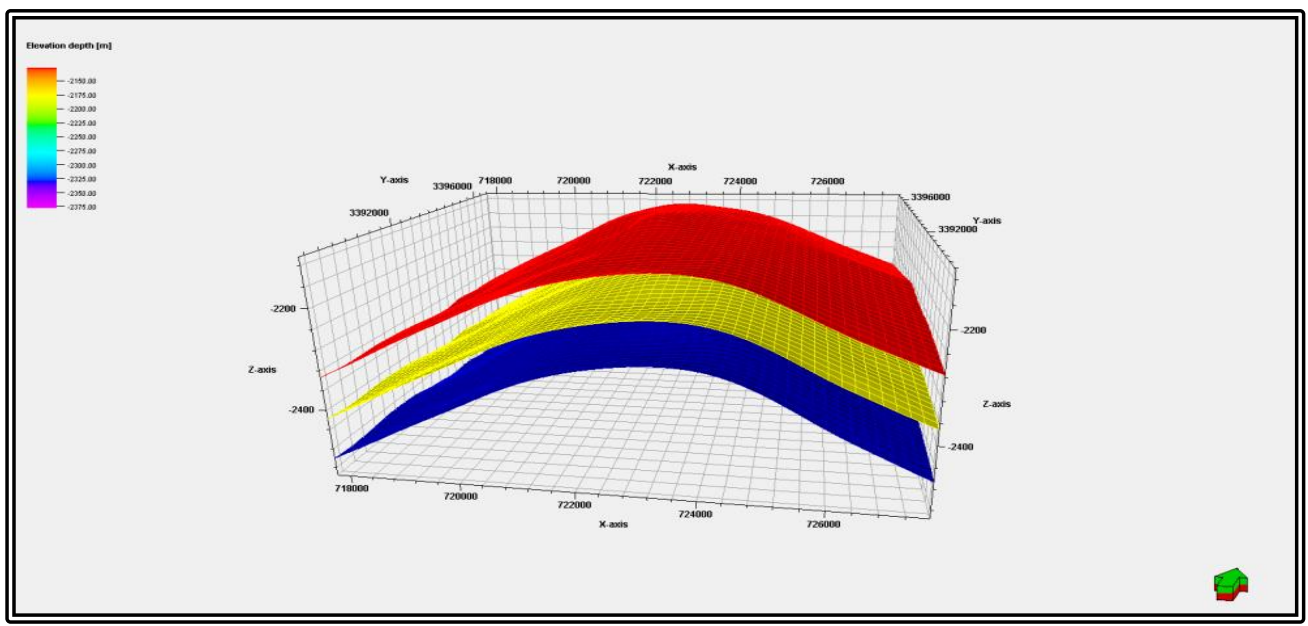

Figure 11-The skeletons of the sector

Usually, 3D grid properties homogenization is considered the ultimate execution step during geological or static modeling, after which the reservoir simulation modeling was ready to be applied using Eclipse software. The petrophysical properties were subjected to modeling using an adequate geostatistical method, the SGS (Sequential Gaussian Simulation), as executed in PETREL [12]. Figure-12 shows an example of porosity modeling for the $\mathrm{mA}$ layer.

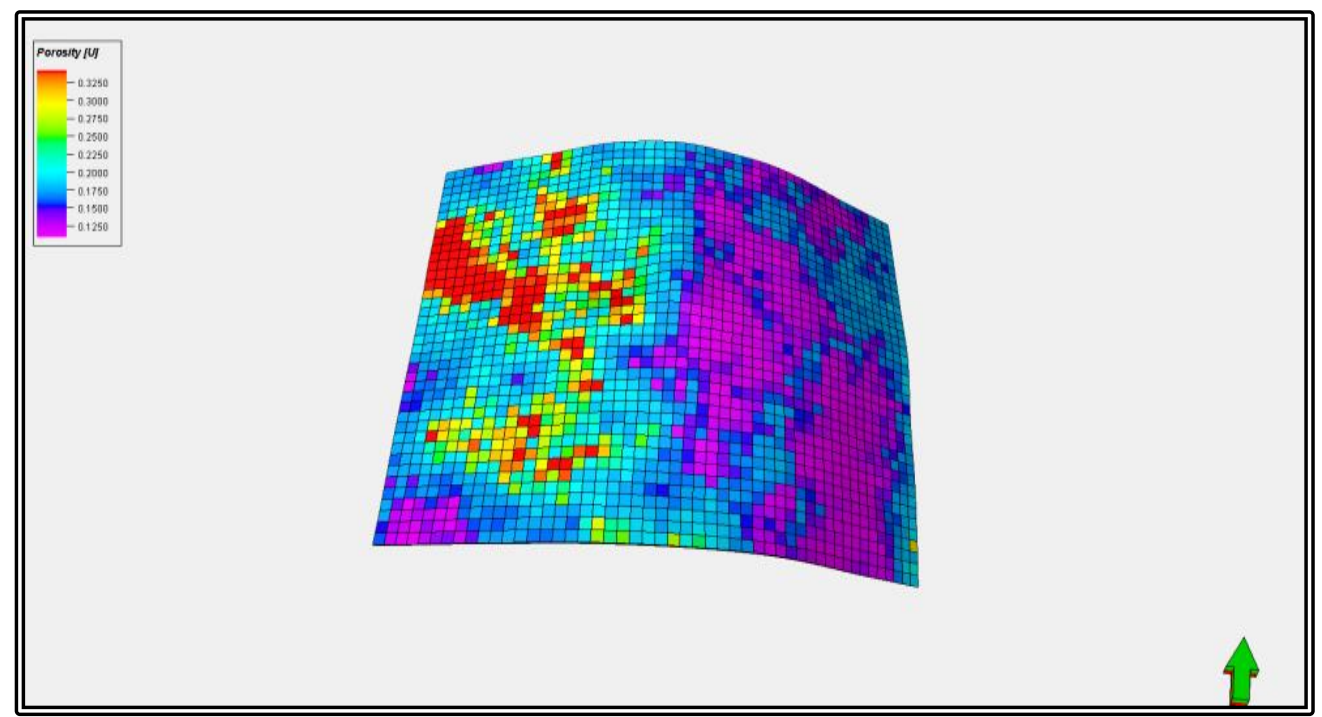

Figure 12-Porosity distribution for unit MA MHF 5

After modeling the sector geologically, numerical modeling was acquired for the matching process. The input data for the model were as follows:

1- Grid block geometry, size, and elevation, which were discussed in the previous section. The areal dimensions were $200 \mathrm{~m}$ by $200 \mathrm{~m}$ and the vertical one depended on the layering model (86 layers), while the total number of cells or grids was 170519 grid blocks.

2- Porosity and horizontal permeability, that were described previously, and the relationship between horizontal and vertical permeability obtained from core analysis by the following equation:

$$
\boldsymbol{K} \boldsymbol{H}=1.33 * \boldsymbol{K} \boldsymbol{V}^{\mathbf{1 . 0 4}}
$$

3- The data of capillary pressure and relative permeability that are applied for the determination of initial and connate water saturation and fluids movement.

4- PVT analysis data of reservoir fluids with oil properties that are related to well R-059, as this well is included in the sector modeling of the current study, whilst saturation pressure was about 2100 psi.

5- Well locations, completions, and perforated intervals (from CPI) for each well. 
6- Production data (oil flow rate, water cut, gas/oil ratio, water injection rate, bottom hole pressure, and static pressure) for all individual wells in the sector, which are 12 wells involved in the history matching process.

7- Initial conditions of Mishrif reservoir. This point refers to the depth of oil-water contact in Mishrif formation, which is $2447 \mathrm{mKB}$, and the initial pressure of the reservoir at this depth, which is approximately equal to 3900 psi.

8- Boundary conditions of the sector. Basically, Mishrif formation/North Rumaila field has no flow boundary with both east and west flanks, a flow boundary in the north with West Qurna field, and a saddle that separates North Rumaila from South Rumaila. The sector represents a small part of the entire Mishrif reservoir which was taken from the middle area of the reservoir. Consequently, flow boundaries around the sector were acquired. This could be solved either by additional grid-blocks or three phase tank-cell, as Bruijnzeels and Halloran (1995) included in their study. Additional wells were included in the model (only well tops and log data) to add several grid blocks around this sector, which leads to fix the boundary of the model, resulting in the simulation of these blocks in future developments as they are represented by actual field properties.

After the definition of all the above input data to the reservoir model, the final step was to run the model using PETREL 2016 as well as ECLIPSE 100 simulators to verify the validity of this model.

A history match analysis for the immediate study was carried out for the sector model from December 1974 to the end of 2018. The wells that were historically matched in this study are R-059, R-069, R-138, R-203, R-280, R-309, R-315, R-399, R-412 and R-415, as production wells only, while R-397 and R-414 were producers which then converted to injectors. The matching was achieved for oil production rate, water production rate, cumulative oil production, static reservoir pressure, and bottom hole flowing pressure. Figures-13 illustrates matching between observed and actual data for the full sector.

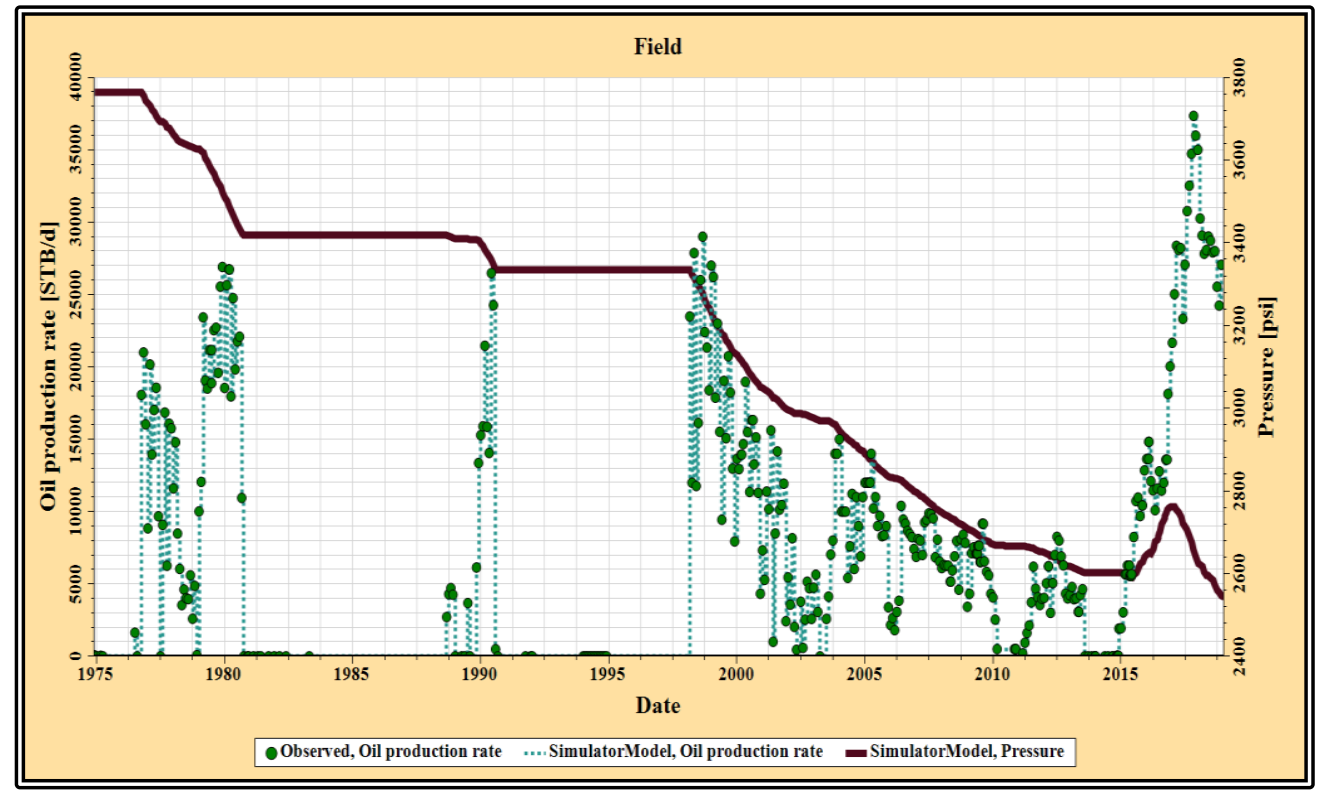

Figure 13-Observed and calculated field oil production rate with the simulated pressure.

The history matching process indicates a reasonable matching between available actual data and simulator output results. This indicates that most of the water-cut is caused from the flooding strategy. Moreover, there is a noticeable decrease in the average reservoir pressure.

In the developing plan, a single case was carried out that was aiming to achieve a target oil rate, constantly about $75000 \mathrm{STB} /$ day, for the sector. For this purpose, the wells were distributed in groups with different production and injection schedules. Moreover, the wells were subjected to workover processes and possibility of converting producers to injectors. Flowchart_1 shows the main inputs to the model, while Figures-(14 and 15) illustrate reservoir pressure, injection and production rate, cumulative oil rate, and water-cut. Finally, Figure-16 displays the main results (events) presented during the case's running time. 


\begin{tabular}{|c|}
\hline $\begin{array}{c}\text { Full Sector } \\
\text { - Oil production rate }=75,000 \text { STB/day (target) } \\
\text {-Water injection rate depends on rate of injectors }\end{array}$ \\
\hline $\begin{array}{c}\text { Poduction group A } \\
\text { •Includes R-069 \& R-415 } \\
\text { •Oil Rate limited, Qo } \leq 20000 \text { STB/day }\end{array}$ \\
\hline $\begin{array}{c}\text { Poduction group B } \\
\text { •Includes R-059, R-203 \& R-315 } \\
\text { •Oil Rate limited, Qo } \leq 15000 \text { STB/day }\end{array}$ \\
\hline $\begin{array}{c}\text { Production group C } \\
\cdot \text { Includes R-412 } \\
\cdot \text { Oil Rate limited, Qo } \leq 8000 \mathrm{STB} / \text { day }\end{array}$ \\
\hline $\begin{array}{c}\text { Poduction group D } \\
\text { •Includes R-138, R-280 \& R-399 } \\
\text {-Oil Rate limited, Qo } \leq 8000 \text { STB/day }\end{array}$ \\
\hline $\begin{array}{l}\text { Production wells (AlI) } \\
\cdot \text { W.C }>0.4 \text { shut-in worst intervals (plugged) } \\
\text { •Possibility of conversion to injector } \\
\cdot \text { BHP }<2200 \quad \text { Close Well }\end{array}$ \\
\hline $\begin{array}{c}\text { Injection group A } \\
\bullet \text { Includes R-397 \& R-414 } \\
\bullet \text { Water Injection Rate = 30,000 STB/day } \\
\bullet \text { BHP }>5500 \text { (fracture pressure) Stop Injection }\end{array}$ \\
\hline $\begin{array}{c}\text { Injection group B } \\
\bullet \text { Includes R-309inj \& R-412inj } \\
\bullet \text { Water Injection Rate }=25,000 \mathrm{STB} / \text { day } \\
\bullet \text { BHP }>5500 \text { (fracture pressure) Stop Injection }\end{array}$ \\
\hline
\end{tabular}

Flowchart 1- Roles and constraints for the developing plan

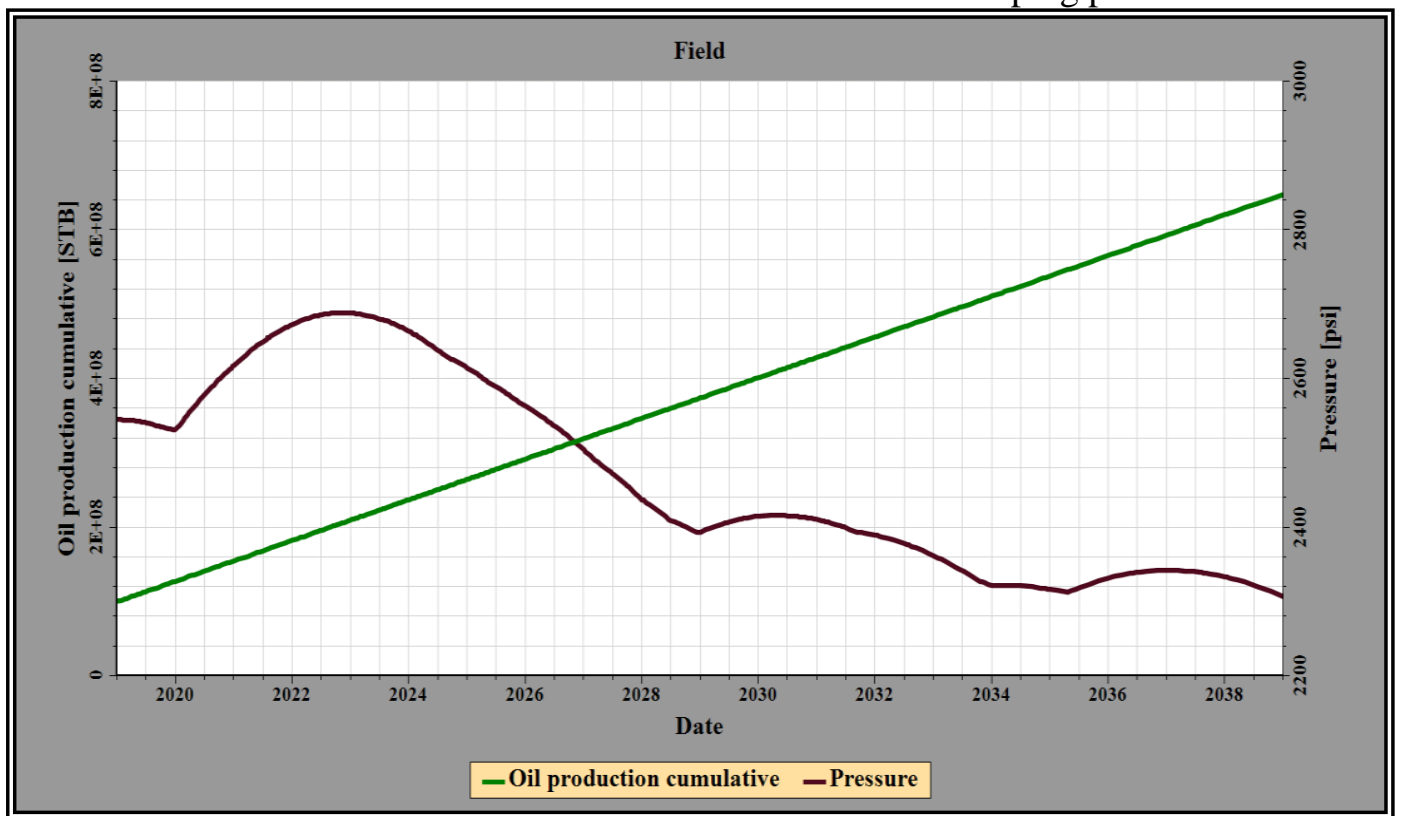

Figure 14-Pressure and cumulative oil of the plan. 


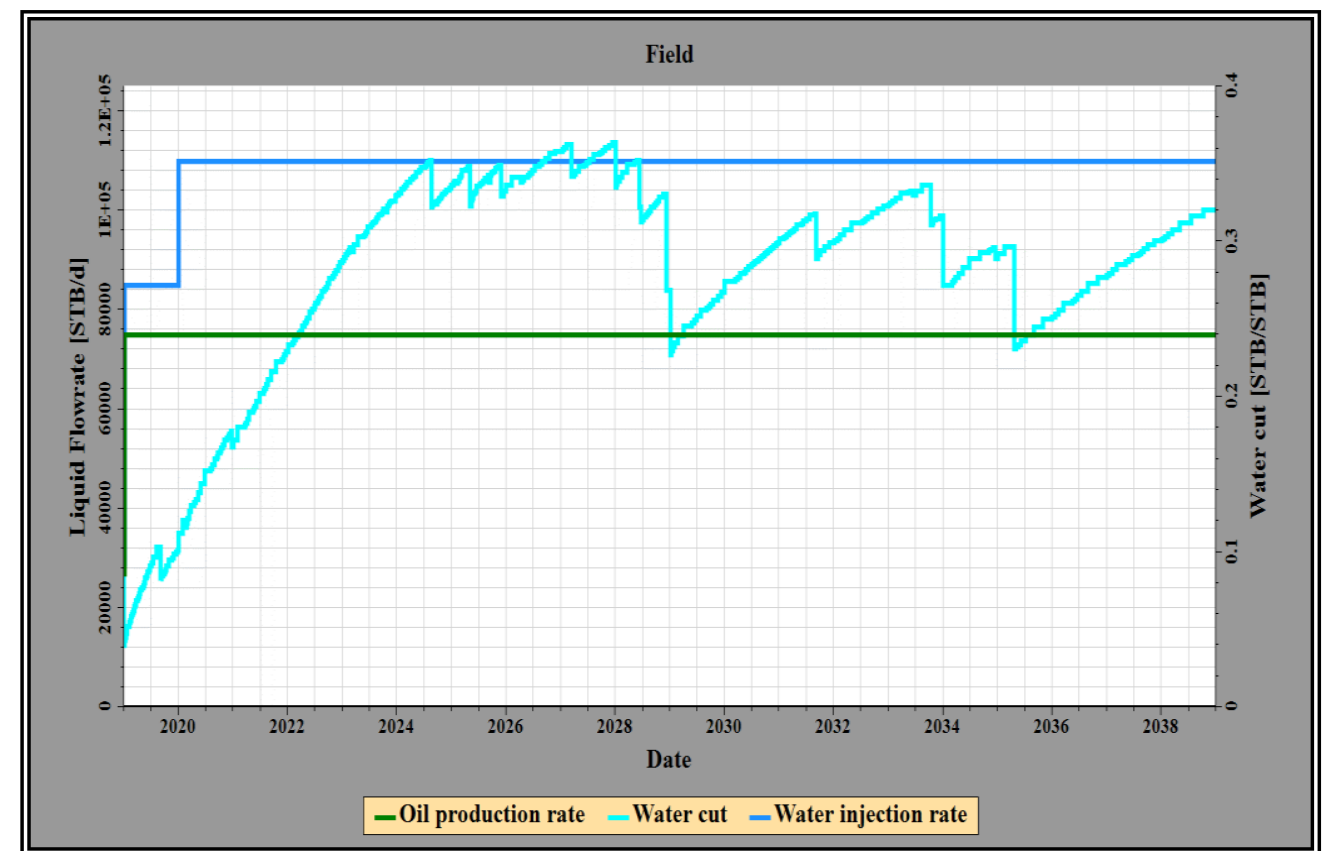

Figure 15-Rates of oil production and water injection with water-cut.

\begin{tabular}{|c|}
\hline $01 / 01 / 2019$ \\
\hline $\begin{array}{l}\text { - Run the case, All producers and injectors are online } \\
\text { - R-309 converted to injector } \\
\text { - Total oil rate = 75,000 STB/day (Target) } \\
\text { - Water injection rate = 110,000 STB/day } \\
\text { - Perforation intervals added to R-280, R-138, R-059 \& R-203 } \\
\text { - Average pressure = } 2545 \text { psi }\end{array}$ \\
\hline Aug. 2019 to Dec. 2020 \\
\hline $\begin{array}{l}\text { - } R-280 \text { and } R-138 \text { bottom interval was plugged due to } \\
\text { W.C }>0.4 \\
\text { - R-412 shut-in then converted to injector. }\end{array}$ \\
\hline from 2023 to 2030 \\
\hline $\begin{array}{l}\text { - R-059, R-315, R-399 and R-415 were plugged in bottom intervals } \\
\text { due to W.C }>0.4\end{array}$ \\
\hline from 2031 to 2036 \\
\hline $\begin{array}{l}-R-069 \text { \& R-203, were plugged in bottom intervals due to W.C } \\
>0.4\end{array}$ \\
\hline $01 / 01 / 2039$ \\
\hline $\begin{array}{l}- \text { End the case } \\
\text { - Pavg = } 2307 \text { psi } \\
\text { - Cumulative oil = 6.4911E+08 STB }\end{array}$ \\
\hline
\end{tabular}

Figure 16-The main events occurred throughout the developing plan.

\section{4- Conclusions}

1) Instead of full field, a sector modeling was chosen for the simulation process as the timeframe

2) of the matching process is much shorter. In addition, the sector provided an elastic way for geological hypothesis and optimized well spacing in comparison with the full-field model.

3) Boundary conditions for the modeled sector were treated by grid-blocks attachment to the sector, which represented unsimulated portions around the sector. These blocks were added based on 
wells located close to the sector. Moreover, two injection wells were included for the matching process and they were considered as phantom or pseudo wells.

4) Two sets of core data were employed for Pc curves, namely initialization and relativepermeability, so that the sector was modeled based on two hydraulic units. Pc curves showed that the thickness of Mishrif transition zones is minimum, which resulted from less density differences between formation water and oil, as Mishrif formation water is considered close to fresh. Although the data are assigned for each of the units that are having different initial water saturation, they are the only available data for the model and have given an accepted result in history matching.

5) Although the PVT data were available for more than one well, R-059 well data were selected for sector fluid characteristics, as it was included in the sector.

6) History matching was performed for time duration from 1974 to end of 2018. The matching process was conducted depending on flowing data and static pressure data. A good point of matching was the available water-cut data that showed that most of produced water resulted from the injection process, as production was achieved after a period water injection. Consequently, the matching process showed the effect of injected water on reservoir pressure and production schedules.

7) In the development plan, there was not even a single well that has been added to the sector for future development. Instead, the available wells were constructed to achieve production targets. Moreover, Mishrif formation in North-Rumaila has been producing with more than 500 wells (producers and injectors) and spacing values that range from 2000 meters to 700 meters. Thus, the production was carried out without the necessity of additional wells in the studied sector. As displayed in the plan, the production total rate was constant along production time because of the workover processes.

\section{5- Acknowledgments}

The authors would like to thank Basra Oil Company for providing the required data to achieve this study.

\section{References}

1. Yixiang, Z., Xinmin, S. Benbiao, S., Shuiqing, H., Changbing, T., Yan, G., Weimin, Z. and Yong, L. 2017. "SPE-187235-MS Genesis of High Permeable Thief-zones and Integrated Reservoir Modeling of Intense Heterogeneous Reef-flat Carbonates: A Case Study for the Mishrif Formation of the Rumaila Oilfield, Iraq," pp. 1-12.

2. Benedek, L., Almajid, M., Alhuthali, A.H. and Aramco, S. 2013. "SPE 168089 Integrated Reservoir Management Approach to Improve Injection Efficiency in a Low Transmissibility Sector of a Giant Carbonate Reservoir," 1: 1-11, 2013.

3. Lazim, S.R. 2013. "Determination of Optimum Injection Patterns for Carbonate Reservoir (Mishrif Formation/ Tuba Oil Field) by using Reservoir Modeling," no. April.

4. Dzyuba, V.I., Litvinenko, Y.V., Bogachev, K.Y., Migrasimov, A.R., Semenko, A.E., Eydinov, D.A. and Dynamics, R.F. 2012. "SPE 162090 Application of sector modeling technology for giant reservoir simulations,".

5. Yong, L., Benbiao, S., Baozhu, L., Changbing, T., Yixiang, Z. and Qihao, Q. 2017. "SPE-185856MS Representative Sector Modeling and Key Factors Impact on Waterflooding Performance of a Large Multi-Layered Sandstone Reservoir," 2017.

6. Bruijnzeels, C. and Halloran, C.O. 1995. "SPE 29117 Rabi Multi-Sector Reservoir Simulation Model," pp. 219-232.

7. A. . Aqrawi, J. C. Goff, A. D. Harbury, and F. N. Sadooni. 2010. petroleum geology of Iraq. 2010.

8. Ezekwe, N. 2011. Petroleum Reservoir Engineering practice. Boston: pearson Education, 2011.

9. Tarek, A. 2006. Reservoir Engineering, Third. Elsevier, 2006.

10. Civan, F. 2002. "SPE 73785 Fractal Formulation of the Porosity and Permeability Relationship Resulting in A Power-Law Flow Units Equation - A Leaky-Tube Model,".

11. Haro, C.F. and Oil, O. 2004. "SPE 89516 The Perfect Permeability Transform Using Logs and Cores,".

12. Alaghsood, B. and Corp, A.N. 1996. "Characterization and Flow Modeling of a Heterogeneous Carbonate Reservoir in Daleel Field, Oman," 